UDC 340.12

Hans KÖCHLER

\title{
NORMATIVE CONTRADICTIONS IN INTERNATIONAL LAW: IMPLICATIONS FOR LEGAL PHILOSOPHY
}

\begin{abstract}
In order to be perceived as legitimate by those subject to it, a system of legal norms should be free of contradictions. The very idea of justice is incompatible with an erratic interpretation and, subsequently, arbitrary application of norms. Systemic contradictions make actions by state authorities unpredictable. However, at the domestic as well as at the international level, considerations of power and interest have often made of the respective body of norms a "hermeneutical minefield." The international legal order in particular contains contradictions even between the most basic principles such as state sovereignty, self-determination and the rules of international humanitarian law. While, at the national level, the authority of constitutional courts may help to eliminate contradictions and inconsistencies, there exists, apart from limited regional arrangements, no such separation of powers at the international level. The lecture analyzes, inter alia, the systemic, destabilizing impact of normative contradictions in exemplary cases related to the interpretation of the United Nations Charter and draws conclusions in terms of the philosophy of law.
\end{abstract}

Keywords: Rule of law; validity of norms; justice and law; normative contradictions; jus cogens; sovereignty; national interest; power politics; United Nations.

THE PRECARIOUS NATURE OF THE RULE OF LAW

The stability of any state system, whether national or international, depends on the rule of law. This essentially means general acceptance and consistent enforcement of norms that govern interaction among citizens, at the domestic, or states, at the inter-governmental level. The very rationale of a state, indeed the main justification of its existence, is the capacity to enable its citizens to live free from fear and guarantee their physical integrity. The essence of it is a kind of "social contract" on the basis of mutuality and without "meta- physical" or ideological implications that would privilege only certain groups of society. The major challenge, however, and in the international context in particular, is that it has proven to be virtually impossible to avoid, or eliminate, certain normative contradictions from the respective corpus of norms.

Consistency (A) in the enforcement of norms, i. e. avoidance of double standards, presupposes consistency (B) of the respective system of norms. Domestically, this relates to the Constitution and the body of laws created under it; internationally, the "system" means the corpus of norms regulating relations between states (general as well as customary 
international law), including those of jus cogens, and the ever increasing set of specific norms contained in intergovernmental treaties, particularly the United Nations Charter. If (A) is not guaranteed, we are faced with an erosion of confidence in the system, indeed a loss of legitimacy. If (B) cannot be ensured, the system as such collapses since the very validity of norms is at stake if a Constitutio more generally: a system of norms - contains (logical) contradictions. Although the validity of norms (values) as such cannot be proven in the material sense, i.e. in terms of their content (a normative statement is neither true nor false), logic applies at the formal level, i.e. to the relations between norms, namely questions as to the compatibility of their content. ${ }^{1}$

Strictly speaking, the rule of law remains an abstract ideal if (A) or (B) cannot be ensured. While the requirements under (A) can - in principle at least - be fulfilled on the basis of sincerity and good will of state authorities, and under the watchful eye of an active citizenry, those under (B), pertaining to the very integrity of the respective system of norms and to doctrinaire issues, are an entirely different matter. In actual fact, contradictions between norms are often overlooked or covered up, whether for reasons of "legistic" convenience or political expediency the latter often as a result of power interests

For details see the author's considerations: "Zum Verhältnis von logischen Prinzipien und Rechtsnormen," in: Hans Köchler, Philosophie - Recht - Politik: Abhandlungen zur politischen Philosophie und zur Rechtsphilosophie. (Veröffentlichungen der Arbeitsgemeinschaft für Wissenschaft und Politik an der Universität Innsbruck, Vol. IV.) Vienna, New York: Springer, 1985, pp. $9 \mathrm{ff}$. or, more precisely, power politics, described as "realpolitik" at the global level.

We shall concentrate here on the latter, namely contradictions between norms in the political context. Unavoidably, we can only elaborate on some of the most striking and potentially destabilizing cases of normative conflicts.

\section{TYPES OF CONTRADICTIONS \\ BETWEEN NORMS IN THE INTERNATIONAL CONTEXT}

In relations between states, confusion resulting from irreconcilable normative conflicts abounds. Not only is the body of norms subsumed under the term "international law" law only in very rudimentary form - as there exists no universal and consistent mechanism of enforcement; there effectively exists no separation of powers either to adjudicate such conflicts. The International Court of Justice, part of the edifice of the United Nations Organization, is not the "constitutional court" of the international community. The sheer number of contradictions risks undermining the very legitimacy of the United Nations and may make the "international rule of law" an elusive goal.

There are essentially two types of normative inconsistencies of which we shall highlight some of the most striking ones, with far-reaching consequences for the stability and reliability of the system of inter-state relations. We are dealing (a) with strictly logical contradictions, i.e. incompatibilities of normative content, as in the case of "sovereign equality" vs. inequality derived from special privilege as embodied in the veto power of certain member states of the UN Security 
Council. $^{2}$ (In this context, both "equality" and "inequality," are to be understood in the normative, not factual, sense.)

The second type of inconsistencies (b) results from ambiguity in regard to the hierarchy of norms in the international system. This particularly relates to the status of jus cogens of general international law. One of the most obvious examples is the conflict between the norm of non-interference, derived from national sovereignty, and fundamental norms of human rights. Do norms of a higher category effectively abrogate those of a less basic nature? (The question is similar to the normative conflict in a domestic system where the individual's right to property may, in certain cases, be subordinated to considerations of the common good. In such cases, however, there are elaborate judicial procedures to resolve the conflict on the basis of the respective constitution.) The dilemmata resulting from and controversies surrounding practices of "humanitarian intervention"3 - or actions under the "Responsibility to Protect"

2 On the implications of this contradiction for collective security and the international rule of law see the author's analysis: The Voting Procedure in the United Nations Security Council: Examining a Normative Contradiction and its Consequences on International Relations. (Studies in International Relations, Vol. XVII.) Vienna: International Progress Organization, 1991.

3 For normative contradictions and moral dilemmata see the author's analysis: The Concept of Humanitarian Intervention in the Context of Modern Power Politics: Is the Revival of the Doctrine of "Just War" Compatible with the International Rule of Law? (Studies in International Relations, Vol. XXVI.) Vienna: International Progress Organization, 2001. doctrine, to use the more recent term - have made drastically obvious that, in actual state practice, there exists no consensus on the hierarchy of norms that would allow to resolve those normative conflicts. To the contrary, disagreement on these doctrinaire issues has further fueled international tensions as in the cases of the use of force against Iraq (2003), Libya (2011), and, more recently, Syria. Can norms, enshrined in the United Nations Charter, such as that of "sovereign equality," be defined as relative, i. e. subordinated to the validity of other norms such as human rights, understood as jus cogens of general international law? Can one, in fact, argue in favor a general "human rights caveat" that would be tantamount to the "measuring" of every other norm of international law against standards on which there is, as of yet, no agreement as to their specific meaning? The question of "who adjudicates?" in cases of disagreements cannot be answered under the present conditions. In the absence of legal mechanisms, i.e. without a separation of powers with an International Court of Justice with compulsory jurisdiction as an integral part, ${ }^{4}$ the risk is that these normative conflicts and disagreements are resolved by resort to the arsenal of power politics, not the instruments of law.

We shall exemplify the above types of contradictions in different areas and respects, relating to: (a) the normative consistency of the Charter of the United Nations Organization and of the body of norms of international

4 According to Article 94(2) of the UN Charter, enforcement of judgments of the ICJ by the Security Council is at the discretion of the Council, which is not compatible with the idea of compulsory jurisdiction in a context of a separation of powers. 
criminal law; (b) the overall compatibility between different bodies of international law and specific treaties ("systemic consistency" of contemporary international law); and (c), on an exemplary basis, contradictions between specific maxims of international law. The issues will be demonstrated, in particular, in regard to the legal status and doctrinaire evaluation of the international use of force, of national sovereignty and of human rights. The enumeration of 10 exemplary cases - most of which, most of the time, are hidden from public scrutiny - will be followed by questions as to the reasons behind these contradictions and inconsistencies and by a reevaluation of the meaning of "rule of law" in the international context.

Contradictions within the United Nations Charter

(1) Principle of sovereign equality (Article 2[1] of the UN Charter) versus the norm underlying the veto privilege of the Security Council's permanent members (Article 27[3] of the UN Charter):

The rule that all decisions of the Council other than procedural ones require the consent of the five permanent members ${ }^{5}$ makes the notion of equality of all member states, derived from the principle of sovereignty, ${ }^{6}$ void of any legal meaning. If one of the basic principles of the world organization is effectively invalidated by a norm on decision-making in the body vested with supreme executive power, the entire edifice of the UN Charter is - due to this normative inconsistency - on

Article 27(3).

6 Article 2(1): "The Organization is based on the principle of the sovereign equality of all its Members." shaky ground. In actual fact, this means that the norm of equality strangely "coexists" in the UN Charter with its very antithesis, namely the (unspoken) norm of inequality. It goes without saying that a logical contradiction between the contents of norms, in fact a conflict with one of the system's basic principles, makes it impossible to characterize such a system as in conformity with the rule of law. It may more appropriately be characterized as a system of political, not legal, rules and regulations.

(2) Ban on the use of force (Article 2[4] of the UN Charter) versus the effective reintroduction of jus ad bellum because of the non-abstention clause of Art. 27(3) of the Charter:

The principle that all member states "shall refrain in their international relations from the threat or use of force" becomes virtually meaningless as regards the permanent members' "accumulated privilege" of (a) preventing any resolution of the Council on matters under Chapter VII (collective security) by withholding their consent, and (b) being free from the obligation to abstain in a case where a permanent member is itself "party to a dispute," as in the very case mentioned in Article 2(4), namely an act of aggression "against the territorial integrity or political independence" of another state. As the veto rule itself, circumscribed as the requirement of the "concurring votes of the permanent members" (Article 27[3]), this additional decisionmaking rule is introduced only obliquely, namely by implication, insofar as the Article stipulates that the indicated voting 
procedure (including the veto privilege) is to be understood under the condition ("provided that") that in decisions under Chapter VI (which deals with non-binding measures on the peaceful settlement of disputes) a party to a dispute "shall abstain from voting." Ergo, the obligation to abstain does not apply to decisions under Chapter VII. This provision applies to all members of the Security Council, permanent and non-permanent, but in combination with the veto right it becomes a tool of power politics by which a permanent member can prevent the Council from taking coercive measures against its own acts of aggression. The Council will, thus, always be paralyzed when it comes to the most serious transgressions of international law by its permanent members. There is a special irony in the fact that for non-enforceable decisions (under Chapter VI) a higher standard, namely the obligation to abstain in case of involvement in a dispute, applies than for binding, enforceable resolutions (by use of armed force) under Chapter VII (in cases of "threats to the peace, breaches of the peace, and acts of aggression"). Again, as under (1) above, it goes without saying that such an outright contradiction between the general rule of justice nemo judex in causa sua (heeded by the Charter in regard to less important, i.e. non-binding decisions) and a decision-making rule (privilege) in the field of collective security (i.e. coercive measures) makes the idea of the rule of law in relations between states void of any meaning.
(3) Non-interference in the internal affairs of states (a norm generally derived from the principles in Articles 2[1] and 2[4], and affirmed as binding upon the world organization in its own actions in Article $2[7])$ versus the right to intervene according to the doctrines of "humanitarian intervention" or "Responsibility to Protect" (R2P), both of which are based on the interpretation of human rights as jus cogens of general international law:

As explained in the introductory remarks of chapter (B) above, this normative conflict may only be resolved if consensus can be reached in the international community on the hierarchy of norms and if there is an independent, impartial body to decide on the use of force and its scope. The UN Security Council's coercive powers are tied to its role in the preservation of peace and security and may only indirectly be activated for a collective use of force with humanitarian purpose, namely if the Council, under Article 39 of the Charter, determines that a situation of human rights violations or a humanitarian emergency in a member state constitutes a "threat to the peace." However, the crux of the matter is that the Council, for reasons partly explained under (1) and (2) above, can not act as arbiter in cases of fundamental rights. Because of the voting procedure of Article 27(3), the Council effectively operates as a political organ. Notwithstanding the solemn collective commitments to the Principles of Article 2, its decisions are dictated by considerations of power politics, not by a fundamental concern for the preservation 
of human rights. ${ }^{7}$ Furthermore, the Council's vast coercive powers, in tandem with its de facto legislative authority and quasi-judicial competence it has arrogated in recent years, ${ }^{8}$ make it prone to arbitrary action. Furthermore, a practice of double standards is the inevitable result of the veto privilege of the permanent members. If the basic norm of state sovereignty can indeed be "temporarily" abrogated for the defense of human rights (i.e. in cases of humanitarian emergencies deemed by the Council as threats to international peace and security), arbitrariness resulting from the ever-changing constellation of power and interests among the permanent members defeats the very idea of humanitarian action and negates the legality of such action. The case of Libya, just to mention one of the most recent examples, speaks for itself. ${ }^{9}$

For details see the author's earlier analysis: "The Politics of Global Powers," in: The Global Community. Yearbook of International Law and Jurisprudence, 2009, Vol. I, pp. 173201.

8 On the implications of the change of the role of the Security Council for international legality see the author's analysis: The Security Council as Administrator of Justice? (Studies in International Relations, Vol. XXXII.) Vienna: International Progress Organization, 2011.

9 See, inter alia, MEMORANDUM by the President of the International Progress Organization on Security Council Resolution 1973 (2011) and its Implementation by a "Coalition of the Willing" under the Leadership of the United States and the North Atlantic Treaty Organization. International Progress Organization, Doc. P/22680c, Vienna, 26 March 2011,
(4) Self-determination of peoples (Article $1[2])$ as purpose versus state sovereignty (according to Article 2[1]) as principle of the United Nations:

An irreconcilable normative conflict exists between a state's right to preserve its territorial integrity, derived from the principle of sovereignty (to be respected by all states on the basis of mutuality), and the right of peoples to determine themselves their form of political organization, including the decision to which sovereign entity they eventually want to belong. In the contemporary system of international law, self-determination has the status of a fundamental human right. ${ }^{10}$ The United Nations Charter, nonetheless, leaves the question of that right's status in relation to national sovereignty in limbo, and the numerous solemn declarations in favor of "self-determination" by the General Assembly have only added to the legal ambiguity. If the right of selfdetermination as collective human right is indeed the foundation of the legitimacy of a state, ${ }^{11}$ if it is invoked as legal (not only moral) justification for state creation, it can hardly be argued that its exer-

http://i-p-o.org/IPO-Memorandum-UN-Libya26Mar11.pdf.

10 Article 1(1) of the International Covenant on Civil and Political Rights: "All peoples have the right of self-determination. By virtue of that right they freely determine their political status and freely pursue their economic, social and cultural development."

11 See also Allen Buchanan, Justice, Legitimacy, and Self-determination: Moral Foundations for International Law. Oxford: Oxford University Press, 2004. 
cise is ultimately at the discretion of an existing state. The very notion of "selfdetermination" makes no normative sense if its exercise in a given case depends upon the consent of the state that sees in that very act a threat to its territorial integrity, i.e. a challenge to its sovereign status within the international community, guaranteed by the UN Charter. ${ }^{12}$ This unresolved conflict between two foundational norms of international law has profoundly destabilized the international system and has been the source of political disputes with the threat of extra-legal settlement by resort to armed force. Again, this contradiction exemplifies the precariousness of the international rule of law as guiding principle of a global system of peace.

Contradictions related to international criminal justice

(5) National sovereignty versus universal jurisdiction:

The norm of "national sovereignty," enshrined in the UN Charter as "sovereign equality" of all member states, implies strict adherence to the rule of noninterference into the internal affairs of states (of which criminal jurisdiction is one of the main areas). There are basically two instances where an irreconcilable normative contradiction exists in terms of the exercise of criminal jurisdiction. (a)

12 For an overview of the legal and political issues see Y. N. Kly and D. Kly (eds.), In Pursuit of the Right to Self-determination: Collected Papers \& Proceedings of the First International Conference on the Right to Selfdetermination \& the United Nations, Geneva 2000. Atlanta: Clarity Press, 2001.
The doctrine of "universal jurisdiction," recently incorporated into the legal systems of certain states, ${ }^{13}$ implies the authority of any domestic judiciary to exercise jurisdiction over international crimes irrespective of the nationality of the suspect and the territory on which the alleged crimes may have been committed. ${ }^{14}$ This has led to numerous controversies and disputes among UN member states such as those between Belgium and the United States or Israel over the application of Belgium's war crimes law of 1993. Because of its repercussions on the country's foreign policy, Belgium has eventually modified the law, conditioning its application to a direct connection of a case to the Kingdom of Belgium, thus trying to avoid a conflict over the sovereignty issue. ${ }^{15}$ As such, the doctrine of universal jurisdiction constitutes one of the most serious and far-reaching challenges to the norm of national sovereignty in contemporary international law. ${ }^{16}$

13 This step has in most cases been connected to those states' decision to join the International Criminal Court - in view of the Rome Statute's principle of complementary jurisdiction.

14 For the development of this doctrine see the author's Global Justice or Global Revenge? International Criminal Justice at the Crossroads. Vienna/New York: Springer, 2004, pp. $79 \mathrm{ff}$.

15 For details see op. cit., pp. 93ff.

16 As regards the "sovereign immunity" of state officials, this is also reflected in the judgment of the International Court of Justice (ICJ) in the case of the arrest warrant by a Belgian investigating judge, dated 11 April 2000, against the then Foreign Minister of the Democratic Republic of the Congo: International Court of 
(b) The "creation" of international criminal jurisdiction by fiat of the UN Security Council has often been qualified as violation of the sovereignty of member states. It is an open question whether ad hoc courts such as the Yugoslavia or Rwanda tribunals, established by way of Chapter VII resolutions of the Security Council, are in conformity with international law. ${ }^{17}$ If the creation of courts can indeed be construed as measure to maintain or restore international peace and security according to Article 41 of the Charter, Article 2(7) of the Charter would apply, which provides an exception from the rule of non-interference for all Chapter VII measures. If this were not the case (i.e. if judicial measures cannot be construed as part of the UN system of collective security), the jurisdiction of ad hoc courts would be in strict violation of the norm of national sovereignty. ${ }^{18}$

Justice, Year 2002, 14 February 2002, General List No. 121: [Judgment] Case Concerning the Arrest Warrant of 11 April 2000 (Democratic Republic of the Congo v. Belgium).

17 Concerning the Yugoslavia Tribunal see MEMORANDUM on the Indictment of the President of the Federal Republic of Yugoslavia, the President of the Republic of Serbia and Other Officials of Yugoslavia by the "International Tribunal for Prosecution of Persons Responsible for Serious Violations of International Humanitarian Law Committed in the Territory of the Former Yugoslavia since 1991". International Progress Organization, Caracas, 27 May 1999, at http://i-p-o.org/yu-tribunal.htm.

18 See the author's analysis: "The Security Council and ad hoc international tribunals," in: Hans Köchler, The Security Council as Administrator of Justice? Reflections on the Antagonistic
(6) International humanitarian law versus an interpretation of international law that considers the use of arms of mass destruction as legally neutral act of warfare:

According to the norms of international humanitarian law, the indiscriminate targeting of civilians constitutes a war crime. "War crimes" are defined as "international crimes" which concern the community of states as such and over which - since the Nuremberg and Tokyo tribunals in particular - international criminal courts (such as the International Criminal Court) have jurisdiction. The use of arms of mass destruction, in particular nuclear arms, makes the distinction between civilian and military targets effectively impossible. It has thus been argued that the use of such arms is per se incompatible with international law. As regards nuclear arms, this was clearly stated, inter alia, by the General Assembly of the United Nations. In a resolution adopted on 15 December 1983, the member states declared: The General Assembly "Resolutely, unconditionally and for all time condemns nuclear war as being contrary to human conscience and reason, as the most monstrous crime against peoples and as a violation of the foremost human right - the right to life." ${ }^{19}$ In an Advisory Opinion, requested by the UN

Relationship between Power and Law. Studies in International Relations, Vol. XXXII. Vienna: International Progress Organization, 2011, pp. 17-47.

$1997^{\text {th }}$ Plenary Meeting, A/RES/38/75 ("Condemnation of nuclear war"), Paragraph 1. 
General Assembly, ${ }^{20}$ the International Court of Justice determined, inter alia, and with a caveat "in an extreme circumstance of self-defence," "that the threat or use of nuclear weapons would generally be contrary to the rules of international law applicable in armed conflict, and in particular the principles and rules of humanitarian law." ${ }^{21}$ International humanitarian law would thus be rendered obsolete, indeed void of any normative content, if it were perceived as not applicable in cases of the most extreme violations, namely the use of arms of mass destruction. The inherent normative contradiction would also totally undermine the meaning and statutory position of human rights in the international system.

(7) The prohibition of the indiscriminate targeting of civilians under international humanitarian law versus a restriction of the jurisdiction of the International Criminal Court in cases of the use of nuclear arms, i.e. in a matter of international criminal law:

Related to the above-described contradiction (paragraph 6) is a normative conflict implied in the position of France concerning the jurisdiction of the International Criminal Court. In an "interpretive declaration" made upon ratification of the Rome Statute, France has stated that the

${ }^{20}$ Resolution 49/75, 15 December 1994 ("Request for an advisory opinion from the International Court of Justice on the legality of the threat or use of nuclear weapons").

21 International Court of Justice: Legality of the Use by a State of Nuclear Weapons in Armed Conflict. Advisory Opinion, Year 1996, General List No. 93, 8 July 1996.
Court's jurisdiction over war crimes solely relates to cases where conventional weapons are used. It specifically excluded the use of nuclear arms from jurisdiction of the Court, stating that Article $8(2)(b)$ - that deals with intentional attacks on civilians - only covers conventional warfare. ${ }^{22}$ Although the declaration further stated that this exclusion from jurisdiction will only prevail as long as there exists no comprehensive ban on the use of nuclear arms - which would have to be specified in an annex to the Rome Statute by way of an amendment, the declaration effectively amounts to a "reservation," something which is explicitly excluded in the Rome Statute (Article 120). Should this unilateral declaration by France (that effectively undermines the Court's jurisdiction) be accepted, the International Criminal Court's jurisdiction over war crimes would become totally meaningless since this reading of the Statute would only allow the investigation and prosecution of "minor" crimes while the potentially gravest violations would be beyond the reach of the law. For a legal critique, the interpretive declaration of France should also be validat-

22 "The provisions of article 8 of the Statute, in particular paragraph 2(b) thereof, relate solely to conventional weapons and can neither regulate or prohibit the possible use of nuclear weapons ..." United Nations, Multilateral treaties deposited with the Secretary-General Treaty I-XVIII - 10. "Rome Statute of the International Criminal Court, Rome, 17 July 1998." 
ed in the context of the ICJ's Advisory Opinion on the use of nuclear weapons. ${ }^{23}$ Contradictions related to issues of jurisdiction of the International Criminal Court

(8) International treaty law versus international criminal law:

Article 34 of the Vienna Convention on the Law of Treaties ${ }^{24}$ states that "[a] treaty does not create either obligations or rights for a third State without its consent." This norm is contradicted by the provision of Article 13(b) of the Rome Statute of the International Criminal Court. According to this rule, the United Nations Security Council is given the right to "refer" - by way of a Chapter VII resolution - a situation in which one or more crimes referred to in Article 5 of the Court's Statute $^{25}$ "appears to have been committed." This applies irrespective of whether the State on the territory of which the crime may have been committed, or whose citizen may have committed the crime, is party to the Rome Statute or not. The Security Council has made use of this "privilege" - to "create" jurisdiction where it would otherwise not exist - in the cases of Sudan ${ }^{26}$ and Lib-

23 Fn. 26 above.

24 Concluded on 23 May 1969, entered into force on 27 January 1980.

25 Crime of genocide; crimes against humanity; war crimes; crime of aggression.

26 Resolution 1593 (2005) adopted by the Security Council at its 158th meeting, on 31 March 2005. For details see the Statement of the International Progress Organization: Double Standards in International Criminal Justice: The Case of Sudan. Vienna, 2 April 2005, http://www.i-p-o.org/Koechler-Sudan-ICC.pdf. $\mathrm{ya}^{27}$ against whose state leaders and other officials the ICC subsequently issued indictments. That this provision is prone to political abuse has also become obvious in the fact that permanent member states of the Security Council not party to the Rome Statute (i.e. who reject the jurisdiction of the Court in principle) ${ }^{28}$ have enabled the Council to adopt those resolutions. ${ }^{29}$ Apart from the normative contradiction, this has introduced an element of political inconsistency and arbitrariness in so far as states, for political motives, may make use, in a particular case, of a norm, which they reject in all other cases, and especially as far as their nationals are concerned. This means that the Rome Statute of the International Criminal Court not only contradicts international treaty law and, subsequently, the principle of sovereign equality of States, but also subordinates the Court's jurisdiction to a body that operates outside, and above, the Court's jurisdiction, giving the Council higher rights than the States Parties of

${ }^{27}$ Resolution 1970 (2011) adopted by the Security Council at its 6491st meeting, on 26 February 2011.

28 As regards the United States, cf. the letter, dated 6 May 2002, from John R. Bolton, Under Secretary of State for Arms Control and International Security, to the Secretary-General of the United Nations: Multilateral treaties deposited with the Secretary-General - Treaty IXVIII - 10. "Rome Statute of the International Criminal Court, Rome, 17 July 1998," Note 6.

29 In the case of the Sudan resolution, the United States and China, both not parties to the Rome Statute, abstained. In the case of Libya, the resolution was adopted unanimously. 
the ICC themselves. ${ }^{30}$ The matter could only be redressed if the referral right of the Council were defined in the same way as that of the State Parties, namely linking it to crimes "within the jurisdiction of the Court." $" 31$

(9) International criminal law versus United Nations Charter:

Indirectly related to the above contradiction between international treaty law and international criminal law is a contradiction between the Rome Statute of the ICC and the voting privilege in the Security Council. Article 27 of the Rome Statute ("Irrelevance of official capacity") unequivocally states that " $[\mathrm{t}]$ his Statute shall apply equally to all persons without any distinction based on official capacity., ${ }^{, 32}$ This means that no official can claim impunity for acts in the exercise of national sovereignty. The notion of "sovereign immunity" is alien to international criminal law. This is also evident in the statutes of international ad hoc courts established by the Security Council such as the International Criminal Tribunal for the Former Yugoslavia (ICTY) and the International Criminal Tribunal for Rwanda

30 For details see also The Security Council as Administrator of Justice?, pp. 49ff.

31 Article 14(1) of the Rome Statute.

32 The Article further states: "In particular, official capacity as a Head of State or Government, a member of a Government or parliament, an elected representative or a government official shall in no case exempt a person from criminal responsibility under this Statute, nor shall it, in and of itself, constitute a ground for reduction of sentence."
(ICTR). ${ }^{33}$ Similarly, the doctrine of universal jurisdiction, applied by the domestic judiciary in a number of states, excludes impunity for action in official capacity. $^{34}$

However, as regards the (in itself legally problematic) jurisdiction of the ICC on the basis of Article 13(b) of the Rome Statute, ${ }^{35}$ officials from permanent member states of the United Nations Security Council enjoy de facto impunity, i.e. immunity from prosecution, due to those states' voting privilege under Article 27(3) of the UN Charter. Whenever officials from a permanent member state, or

33 See articles 7(2) and 6(2) respectively of the statutes of the ICTY and the ICTR: "The official position of any accused person, whether as Head of State or Government or as a responsible Government official, shall not relieve such person of criminal responsibility nor mitigate punishment."

34 Following the affirmation by the UN General Assembly of "the principles of international law recognized by the Charter of the Nuremberg Tribunal and in the judgment of the Tribunal" (resolution 177[II] of 21 November 1947), the International Law Commission of the United Nations has drafted this norm in the following way: "Principle III. The fact that a person who committed an act which constitutes a crime under international law acted as a Head of State or responsible Government official does not relieve him from responsibility under international law." For details see also Christopher C. Joyner, "Arresting Impunity: The Case for Universal Jurisdiction in Bringing War Criminals to Accountability," in: Law and Contemporary Problems, Vol. 59, No. 4, Autumn 1996, pp. 153-172.

35 See paragraph 8 above. 
a state allied with the former, might be subjected to the prosecution of the ICC, the concerned state may veto the respective Chapter VII resolution on referral of a situation. Ironically, in a twist of power politics, this provision "neutralizes" the effects of Article 13(b) of the Rome Statute which would allow the ICC to exercise jurisdiction even in cases where officials of states not party to the Rome Statute are suspected to have committed crimes referred to in Article 5 of that Statute. Although this relates to all nationals of the respective permanent member states, the potential implications of Article 13(b) for the heads of state and other high officials from non-state parties of the ICC make the veto provision a particularly powerful tool according to the maxim "might makes right," effectively allowing those states to instrumentalize a statute of international criminal law in the interest of power politics.

In general terms, however, the contradiction exists between a norm regulating the jurisdiction of the ICC, namely Article 13(b) of its Statute, and a norm regulating the voting procedure in the Security Council, namely Article 27(3) of the Charter, potentially "immunizing" all nationals from non-states parties of the Rome Statute insofar as those states are permanent members of the Council. Again, this is a case of judicial inequality of the highest order, effectively linking legal privileges (immunity from prosecution) to a privilege of power politics (the veto provision in tandem with the nonobligation of parties involved in a dispute to abstain from voting on Chapter VII resolutions). ${ }^{36}$

Contradictions related to the status of human rights

(10) Human rights norms versus the rules of the United Nations Charter regarding the coercive powers of the Security Council:

Since the collapse of the global power balance upon the end of the Cold War, the United Nations Security Council has increasingly resorted to the use of economic sanctions as coercive measures under Article 41 of the UN Charter. The most comprehensive sanctions régime to date were the measures imposed on Iraq in the period 1990-2003, mainly victimizing the civilian population. In the pursuit of its mandate under Chapter VII of the Charter, the Council enforced conditions that caused suffering and death to hundreds of thousands of people. ${ }^{37}$ In a deposition before the United Nations Commission on Human Rights, the International Progress Organization, on 13 August 1991, deplored the violation of the most basic human right, the right to life, "by an intergovernmental body [namely the UN Security Council / H.K.] against the population of a member state of the UN.",38

${ }^{36}$ See also paragraph 2 above.

37 See the report The Human Costs of War in Iraq. New York: Center for Economic and Social Rights (CESR), 2003.

38 "Statement by the delegate of the International Progress Organization, Warren A. J. Hamerman, before the United Nations Commission on Human Rights, Sub-Commission on Prevention of Discrimination and Protection of 
Although the Council, under Article 41, enjoys full discretion in the use of coercive measures - not involving the use of armed force - "to maintain or restore international peace and security" (Article 39), including the "complete or partial interruption of economic relations," it must not be overlooked that the consequences of those measures have often meant the denial of the most basic human rights to the affected civilian population, indeed a form of collective punishment. ${ }^{39}$ In these cases, a basic normative contradiction cannot be denied between the validity of human rights, as codified in international covenants, if not as peremptory norms (jus cogens) of general international law, ${ }^{40}$ and the norms regulating the United Nations' mandate for the maintenance or restoration of international

Minorities, on UN sanctions against Iraq and human rights, 13 August 1991." UN Document E/CN.4/Sub.2/1991/SR.10, 20 August 1991.

39 On the legal aspects see also: "The Adverse Consequences of Economic Sanctions." United Nations, Commission on Human Rights, SubCommission on the Promotion and Protection of Human Rights, Fifty-second session, item 12 of the provisional agenda, Economic and Social Council, E/CN.4/Sub.2/2000/33, June 21, 2000: Working paper prepared by Mr. Marc Bossuyt.

40

On the status of human rights norms see, inter alia, Menno T. Kamminga and Martin Scheinin, The Impact of Human Rights Law on General International Law. Oxford, New York: Oxford University Press, 2009. - Predrag Zenović, Human rights enforcement via peremptory norms - a challenge to state sovereignty. RGSL Research Papers, No. 6, Riga Graduate School of Law, 2012. peace and security. ${ }^{41}$ In the ultimate consequence, the "normative dilemma" consists in the Council's need to reconcile the pursuit of two basic "Purposes" stated in Article 1 of the UN Charter, namely the "maintenance of peace" (Par. 1) on the one hand and the "promotion" of respect for human rights (Par. 3) on the other. In spite of the Council's almost absolute powers under Chapter VII, enabling it to interfere into the sovereign domain of member states, the Council, according to Article 24(2), is still required to act "in accordance with the Purposes and Principles of the United Nations," which means that it is also bound by human rights constraints. However, in the absence of a separation of powers within the UN system, ${ }^{42}$ there exists no body with the authority to review coercive (Chapter VII) resolutions of the Security Council in regard to their compatibility with human rights. In the words of a former Secretary of State of the United States: "The Security Council is not a

${ }^{41}$ On the question of the authority of the Security Council see also Mary Ellen O'Connell, "Debating the Law of Sanctions," in: European Journal of International Law, Vol. 13 (2002), pp. 63-79. - On the compatibility issue see also the author's analysis: The United Nations Sanctions Policy \& International Law. Just World Trust: Penang, 1995.

42 The Charter of the United Nations Organization provides for a predominant role of its supreme executive organ, the Security Council, completely marginalizing the role of the General Assembly and the International Court of Justice. As regards the latter, see also Attila Tanzi, "Problems of Enforcement of Decisions of the International Court of Justice and the Law of the United Nations," in: European Journal of International Law, Vol. 6 (1995), pp. 539-572. 
body that merely enforces agreed law. It is a law unto itself."

\section{NORMATIVE CONTRADICTIONS AND POWER POLITICS: CONCLUSIONS OF LEGAL PHILOSOPHY}

Most of the normative contradictions and systemic inconsistencies listed above result from issues related to the international status of the state - in terms of the preservation of (state) power in a global competition over the assertion of "sovereignty" and the "national interest," and in a context that is still only marginally determined by law. ${ }^{44}$ (In view of what was explained under paragraphs 1 and 2 above, there is simply no way to legally restrain the exercise of power by the Security Council's permanent members.)

The predominance of considerations of power politics over the commitment to norms related to individual rights in particular has been the reason why normative conflicts are often "resolved" with a casuistic approach. Which norm is given priority depends on the fluctuation of political interests, defined as the respective "national interest," 45 in an ever-

43 John Foster Dulles, War or Peace. New York: Macmillan, 1950, p. 194.

44 See also the author's earlier analysis: "The United Nations Organization and Global Power Politics: The Antagonism between Power and Law and the Future of World Order," in: Chinese Journal of International Law, Vol. 5, No. 2 (2006), pp. 323-340.

45 On the notion of national interest in the global context see also Hans Morgenthau, In Defense of the National Interest: A Critical Examination of American Foreign Policy. New York: Knopf, 1951. changing global power constellation. This is particularly obvious when and where the norm of national sovereignty is concerned (referred to as "Principle" of "sovereign equality" in Article 2[1] of the UN Charter). When, i.e. under what circumstances, does it trump human rights or norms of international humanitarian and international criminal law, and when does it not?

The American Servicemembers' Protection Act of $2002,{ }^{46}$ ironically labeled the "Hague Invasion Act," tic illustration of what may be at stake in terms of establishing a hierarchy of norms when legal principles are in direct contradiction. This law constitutes a direct challenge to the territorial jurisdiction of the International Criminal Court on the basis of Article 12(2) (a) of the Rome Statute. ${ }^{48}$ In the hypothetical case that a US citizen would be prosecuted for the commission of an international crime, and would be extradited to the Court under Article 89 of the Statute ("Surrender of persons to the Court"), the law provides that "The President [of the United States / H.K.] is authorized to use all means necessary and appropriate to bring about the release of any person de-

${ }^{46}$ United States Congress, American Servicemembers' Protection Act of 2002, H.R. 4775, Public Law 107-206, Sec. 2001-2015, Aug. 2, 2002.

47 "U.S.: 'Hague Invasion Act' Becomes Law." Human Rights Watch, 3 August 2002, at https://www.hrw.org/news/2002/08/03/ushague-invasion-act-becomes-law.

48 The Court may exercise jurisdiction if " $[t]$ he State on the territory of which the conduct in question occurred" is a Party to the Rome Statute. 
scribed in subsection (b) ${ }^{49}$ who is being detained or imprisoned by, on behalf of, or at the request of the International Criminal Court." While, under the Rome Statute, the investigation and eventual prosecution of international crimes committed by nationals of non-States Parties on the territory of a State Party to the Rome Statute is a clear-cut case of jurisdiction of the ICC, for the United States this is an equally clear-cut case of violation of the norm of national sovereignty against which - as a last resort - the use of force, by the United States, on the territory of the Netherlands, the seat of the ICC, would be justified. ${ }^{51}$ In addition to this, Article 34 of the Vienna Convention on the Law of Treaties is also quoted according to which "A treaty does not create either obligations or rights for a third State without its consent." ${ }^{, 52}$ Apart from the legal arguments, this appears to be a matter of the interpretation and exercise of the "national interest" by a permanent member state of the Security Council that is not prepared to accept any judicial restrictions, resulting from treaties concluded by third parties, on the conduct of its foreign and security

49 This relates in particular to United States military and allied personnel and for persons acting in official capacity.

50 Sec. 2008(a).

51 Also in current Security Council terminology, the phrase "all necessary means" includes the use of armed force.

${ }^{52}$ Concerning the U.S. position see, inter alia, Bartram S. Brown, "U.S. Objections to the Statute of the International Criminal Court: A Brief Response," in: NYU Journal of International Law and Politics, Vol. 31 (1999), pp. 855-891; esp. pp. 868ff ("Does the Statute Violate the Law of Treaties?’). policies - for which it anyway enjoys de facto "immunity" due to Article 27(3) of the UN Charter. ${ }^{53}$

As of today, there exists no overarching system of norms, agreed upon among all states, that would make it possible to resolve this conflict (between the exercise of sovereignty and the requirements of international criminal justice) within the normative realm. In spite of its labeling as "the principal judicial organ of the United Nations," 54 the ICJ is not the constitutional court of the international community. In its own interpretation, for instance, it cannot rule on any complaints of member states when the Security Council of the United Nations has acted on the basis of Chapter VII of the Charter. ${ }^{55}$ The inbuilt sys-

53 See ch. B(9) above.

54 Statute of the International Court of Justice, Article 1.

55 This follows, by implication, from the Judgment of the ICJ of 27 February 1998 in the case Libya vs. United States (Questions of Interpretation and Application of the 1971 Montreal Convention arising from the Aerial Incident at Lockerbie (Libyan Arab Jamahiriya v. United States of America), esp. paras. 39-44. The Court ruled: "As to Security Council resolution 731 (1992), adopted before the filing of the Application, it could not form a legal impediment to the admissibility of the latter because it was a mere recommendation without binding effect (...). Consequently, Libya's Application cannot be held inadmissible on these grounds." N.B.: Security Council resolution 731 (1992) was not based on Chapter VII of the Charter, while all later resolutions (adopted after Libya filed its Application) were based on the Council's coercive powers under Chapter VII, which meant - in the interpretation of the Court - that the matters dealt with in those 
temic contradictions in contemporary international law, and in particular within the United Nations system, resulting from an unrestrained exercise of the national interest under the auspices of state sovereignty, have not only made the global order ever more precarious, and even more so in the absence of a balance of power, ${ }^{56}$ but threaten to undermine the very idea of the "international rule of law," embodied by the United Nations Organization.

As a kind of guiding principle of a polity, whether domestic or international, the notion of the "rule of law" makes no sense unless normative contradictions are eliminated - or avenues are seriously pursued to resolve systemic inconsistencies. If not, norms may be declared valid simply on the basis of a priority of interests - which will nurture a legal culture of "anything goes" where arbitrariness replaces reliability and accountability of state behavior. What would be important, in that regard, is that consensus is reached on a precise hierarchy of norms whereby norms of

resolutions were excluded from scrutiny by the ICJ. In their Joint Declaration, annexed to the Judgment, Judges Bedjaoui, Ranjeva and Koroma however stated "that it is not sufficient to invoke the provisions of Chapter VII of the Charter so as to bring to an end ipso facto and with immediate effect all argument on the Security Council's decisions."

56 See also the author's analysis: "The Precarious Nature of International Law in the Absence of a Balance of Power," in: Hans Köchler (ed.), The Use of Force in International Relations: Challenges to Collective Security. (Studies in International Relations, Vol. XXIX.) Vienna: International Progress Organization, 2006, pp. 11-19. higher order derogate those of a lower order. ${ }^{57}$ So far, however, a basic precondition of such a normative syllogism in the inter-state context is not in place: In spite of the vast compendium of definitions produced by the International Law Commission of the United Nations, a "normative hermeneutics" that would assist states to agree on a clear and unambiguous definition of legal terms (even as basic as "self-determination," "sovereignty," "use of force," "self-defense," or "equality") is not in sight - as there exists no general agreement either on what, for instance, constitutes norms of jus cogens. ${ }^{58}$ There is also the obstacle of realpolitik: a more precise definition of those terms will remain a desideratum simply because vagueness is often a requirement of consensus - especially when interests are to be camouflaged in legal terminology.

Apart from the philosophical caveat that makes us aware of the fragile nature of law in the power-centered framework of inter-state relations, there is also a twofold caveat of realpolitik (or, more euphemistically, diplomacy): (a) Contradictions between norms often result from conflicts of interests, and, (b) as far as the United Nations Charter is con-

57 On an earlier effort of the author to establish criteria for such a procedure see: "Die Prinzipien des Völkerrechts und die Menschenrechte: Zur Frage der Vereinbarkeit zweier Normensysteme," in: Zeitschrift für öffentliches Recht und Völkerrecht, Vol. 32 (1981), pp. 528.

58 For a critical assessment see Ulf Linderfalk, "The Effect of Jus Cogens Norms: Whoever Opened Pandora's Box, Did You Ever Think About the Consequences?," in: European Journal of International Law, Vol. 18 (5), pp. 853-871. 
cerned, inconsistencies that are the legacy of a compromise with power politics cannot be eliminated because of the veto. ${ }^{59}$ Due to Article 108 of the Charter, linking amendments to the consent of the permanent members, the world organization is indeed caught in a vicious circle. The predominance of interests over norms leaves the international community - or, more precisely, the system of interstate relations - in a state of limbo that makes the "international rule of law" ever more elusive.

59 See paragraph 1 of chapter (B) above. 